\title{
Looking beyond the horizon. A normative-institutional approach to sustainability science; getting onto 'the balcony'
}

\author{
Michiel A. Heldeweg* \\ Professor of Law, Governance \& Technology, University of Twente, the Netherlands
}

\begin{abstract}
This contribution is based upon an invited keynote to the CSS2020 Conference on Sustainability Science 2020 (Sustainability Science Post COVID-19; Social Distancing Life, Approaching Natural Life, October 8, 2020). Living in the 'Anthropocene' confronts us with major challenges regarding a sustainable and healthy planetary environment. Climate change and biodiversity degradation, but also the COVID-19 pandemic are testimony to this, and together they give cause to consider human responses to them. These responses come with several 'tragic conditions': on managing commons, on looking beyond our horizon, and on handling cognitive ambiguity. How can we institutionally safeguard against these conditions and have a better chance at avoiding disasters and recovering from them? This contribution points at some normative/legal arrangements establishing such safeguards, such as on a proper knowledge infrastructure, on guiding rights \& principles, and on promoting resilience by taking a more system view. It is hoped that these examples will inspire thinking about how 'to climb onto the balcony', look beyond the horizon and act responsibly.
\end{abstract}

\section{Introduction ${ }^{1}$}

The era we live in since the mid- $20^{\text {th }}$ century is named the 'Anthropocene', because since about that time we as humans have obtained the ability to inflict damage to the planet similar to the extent with which an earthquake and a meteorite crushing into the Earth can do so. Aside from warfare, we are probably less likely to cause such sudden impacts, but surely impacts with major and in fact planetary magnitude - and slow disasters are perhaps at least as dangerous as those happening suddenly and presenting themselves as a clear cause for action.

With respect to sustainability of the Earth's environment, climate change, biodiversity degradation and loss of natural resources are key examples of disasters in the making. At the same time, on the side of what may be called the need for a healthy environment, pandemic threats and events such as COVID-19, confront us with the occurrence of zoonotic diseases (i.e., where a pathogen 'jumps' from an animal to a human agent, to then spread amongst humans; as happened with HIV, Ebola, bird and swine flu). While these originate in animals, their 'jump' to humans may actually have much to do with particular (modes of) human practices, amongst which industrial food production and trading [1]. It seems that even when we are not the root cause, our way of life aggravates the impact first by allowing the 'jump' and next by its rapid and large-scale transmission between humans in a globalized world.

I will first, in section 2., make some short, highlighting remarks about climate change and biodiversity degradation, to then move to pandemic risk, and to next address the linkage between environmental and pandemic risks. The challenge behind these risks, the human traits that seem to stand in the way of an effective and efficient response to them, are addressed in section $3 .^{2}$ This will involve a brief look at three of these traits, as human tragedies regarding management of our commons, of looking beyond our experience horizon, and of handling our cognitive-behavioral limitations. In the fourth section, I will point at some of the possible remedies, to overcome the latter tragedies, to then make some concluding remarks in section 5 .

Should one want to see this narrative follow from a leading question, it would be: What institutional safeguards are important to manage three 'human tragedies' as obstacles to overcoming major challenges to a sustainable and healthy environment? As my background is that of a researcher in legal governance, I will seek my safeguards primarily in that area. The adage that supports my quest is that of 'optimism of will over pessimism of the intellect'. ${ }^{3}$

\footnotetext{
* Corresponding author: m.a.heldeweg@utwente.nl
}

\footnotetext{
${ }^{1}$ This being presented as the written, somewhat more elaborate version of an invited (08 October 2020) CSS-conference keynote, the reader should know that it still reflects the nature of a keynote, not that of a typical research article; not only in structure, but also in the more frequent use of popular (internet) sources. Further, as time has moved on since the keynote, on certain points, this contribution could be more focused, leading to sometimes leaving elements out that were already more briefly touched on during the keynote.
} 


\section{Highlighting threats}

Unfortunately, not many words are needed to pinpoint the threats that are the reason behind the CSS conference to which this contribution reflects one of the keynotes. We have become all too aware of them, although opinions about their exact causes \& effects, the seriousness of the latter and the ways to mitigate or adapt to them differ. So, here I focus on indicating the seriousness, to establish the need for action, if only on the basis of taking a precautionary stance. ${ }^{4}$

\subsection{Climate change}

As regards climate change it is said that there is an abundance of evidence that, in the words of the UN News bulletin [3] announcing the IPCC Climate change 2014 Synthesis Report [4], "Global warming is unequivocal, human influence has been the dominant cause since the mid-20th century, and atmospheric concentrations of greenhouse gases, already at levels not seen in at least 800,000 years, will persist for many centuries, (...)." [3]. And as Mark Carney put it, in his 2015 speech at Lloyd's of London, "While there is always room for scientific disagreement about climate change (as there is with any scientific issue) I have found that insurers are amongst the most determined advocates for tackling it sooner rather than later. And little wonder. While others have been debating the theory, you (insurers, MAH) have been dealing with the reality: Since 1980-ies the number of registered weather-related loss events has tripled; inflation adjusted insurance losses from these events have increased from an annual average of around \$10bn in the 1980s to around \$50bn over the past decade." [5]. So, from the financial impacts and insurers' point of view, climate change is an issue to take very seriously as if beyond uncertainty.

In its lifetime, the current generation has witnessed seriously harmful events that are, setting aside debates on human causation, most likely climate-change induced, such as huge droughts, torrential rains, bushfire crises, more frequent and severe hurricanes, a rise in ocean levels, failing crops, dying species, and human migration. And while it is most likely to get even worse, recovery and restoration from these effects are expected to take decades if not centuries, as indicated in the above citation - and still, only if we manage to get our act together. Getting this act together will involve causeoriented action, of climate change mitigation such as by fostering the transition from fossil to renewable energy resources, but meanwhile we also need effect-oriented action, of climate change adaptation, such as by urban planning, given that we are already too late to avoid all consequences.

\subsection{Biodiversity}

At the same time, our planet's biodiversity is also clearly under threat, as demonstrated in the most recent (September 2020) 'Global Biodiversity Outlook report' [6], which highlights the unprecedented decline in biodiversity. Highlights which express that we face an equally unprecedented acceleration of the species extinction rate, with around 1 million animal and plant species now being threatened with extinction, many within this (2020-ies) decade.

It is a most disconcerting realization, that of the 20 Aichi objectives set at the $10^{\text {th }}$ Biodiversity COP in in 2010 Japan, for the 2011-2020 decade [7], to maintain biodiversity, promote sustainable use of natural resources and protect ecosystems, most of which were due to be reached by the end of this year, not a single one has meanwhile been achieved; only six (possibly) partially.

Needless to say, that whether looked upon from an anthropocentric approach (e.g., the human need for food, medicine, safety and recreation), or from an ecocentric angle (i.e., of natural species as in themselves worthy of protection), or indeed from the three objectives of the Convention on biological Diversity (i.e., conservation of biodiversity, sustainable use of biodiversity; fair and equitable sharing of the benefits arising from the use of genetic resources), human failure abounds.

\subsection{COVID-19}

At this point in 2020, given the shared experience with current readers, what need I say about the COVID19 pandemic? Unfortunately, the numbers speak for themselves. So far (on December 24, 2020) 77 million humans caught the virus and almost 2 million persons died - and these numbers are still increasing as many parts of the world are going through a second wave (and sometimes even a third) [8].

There is general agreement about COVID-19's animal origin, and WHO sources say that it appeared on the human stage late 2019 [9]. Furthermore, there is little doubt that human (patterns of) behavior did enable the zoonotic jump from animals to humans, such as through food market practices, but also enhancing chances at and the spread of contamination through human pressure on the environment and through our globalized economy as will also show in the below.

\footnotetext{
${ }^{2}$ The need for these responses to be fair is not explicitly addressed in this contribution. Although I believe this to be (at least) of equal importance to effectiveness and efficiency (and sometimes a necessary condition to them), this contribution has a focus only on the latter two.

${ }^{3}$ This adage is an adaptation from Antonio Gramsci's quote ("I'm a pessimist because of intelligence, but an optimist of will.”), taken from his December 1929 letter from prison [2].

${ }^{4}$ Principle 15 of the Rio-conference of 1992: “Where there are threats of serious or irreversible damage, lack of full scientific certainty shall not be used as a reason for postponing cost-effective measures to prevent environmental degradation." (Also referred to as the 'Better safe than sorry' principle.)
} 
Most of us have meanwhile experienced at least nearby disease and perhaps even human losses, as well as severe and intrusive measures to curb the virus. The latter seem to have increasingly become a matter of debate, ranging from arguing on the dilemmas of balancing between economic and public health interests, to conspiracy theorizing on origins and abatement policies. At the moment of writing this contribution, the good news is that some vaccines have been approved and vaccination has, in some parts of the world, started already [10]. So, hopes are that 2021 will bring a return to normality, though discussions on fair distribution of the vaccine, which will initially come in scarce quantities, have only just started or are ongoing - while the risk of virus mutation remains [11].

\subsection{Heathy and sustainable}

While we can look upon climate change and biodiversity degradations as separate threats to an ecologically sustainable (human) environment, and the COVID-19 pandemic as a threat specific to maintaining a healthy environment, I already alluded to their interconnectedness.

The aforementioned fifth edition of the UN Global Biodiversity Outlook report, emphasizes the importance of biodiversity in addressing climate change, and longterm food security, and concludes that action to protect biodiversity is essential to prevent future pandemics. And in the 2019 IPCC special report on Climate change and Land [12], it reads: "There is robust evidence that agricultural pests and diseases have already responded to climate change resulting in both increases and decreases of infestations (high confidence)." Further, the IPBES Pandemics Report: Escaping the "Era of Pandemics' [13], addresses the relationship between biodiversity and wildlife-trade on the one hand, and pandemic prevention on the other, and also how landuse and climate-change act as drivers of pandemic risk and biodiversity loss. The gloomy message from the executive summary reads: "Without preventative strategies, pandemics will emerge more often, spread more rapidly, kill more people, and affect the global economy with more devastating impact than ever before." Its key causal analysis is summarized as follows: "The underlying causes of pandemics are the same global environmental changes that drive biodiversity loss and climate change. These include land-use change, agricultural expansion and intensification, and wildlife trade and consumption. These drivers of change bring wildlife, livestock, and people into closer contact, allowing animal microbes to move into people and lead to infections, sometimes outbreaks, and more rarely into true pandemics that spread through road networks, urban centers and global travel and trade routes." Increases of (global) consumption and trade, together with demographic pressure, are the root cause of a 'series of emerging diseases', such as Ebola, Zika, Nipah encephalitis, influenza, HIV/AIDS, COVID-19. "An estimated 1.7 million currently undiscovered viruses are thought to exist in mammal and avian hosts. Of these, 631,000827,000 could have the ability to infect humans.", with
“(...) more than five new diseases emerging in people every year, any one of which has the potential to spread and become a pandemic." [13]. Human 'ecological disruption' and 'unsustainable consumption' are regarded as key drivers of pandemic risk, through unsustainable exploitation (e.g., "land-use change, agricultural expansion and intensification, and wildlife trade and consumption"), climate change (e.g., "movement of people, wildlife, reservoirs, and vectors, and spread of their pathogens (..)"), disrupting the 'natural host-pathogen dynamics', and biodiversity loss such as through the creation of "human dominated landscapes (..) able to harbor pathogens that pose a high risk of zoonotic transmission." [13]. The IPBES report clearly expresses the stance that reducing the anthropogenic pressure on the global environment is expected to reduce the pandemic risk.

\subsection{Understand and act?}

While this and other scientific reports so clearly state a call for action, unfortunately the response to this call comes nowhere close to bringing the necessary changes. I fear I have to agree with, for example, Sarah Lunnon, a spokesperson/activist for/of the Extinction Rebellion movement [14], when she remarks: "Neither Covid nor the Climate and Ecological emergency can be considered Black Swan events. Experts have consistently warned us of the risks of both over the years - however it appears the world is ill-equipped to prevent or mitigate for either." [15].

The latter part of this citation, which alludes to social or psychological obstacles that keep us from an effective and efficient response to major environmental challenges, is what the remainder of this contribution will focus upon. While not being an expert in studies of individual and social behavior, nor on cognitive science(s), I will (in section 3.) point to some of the possible explanations from these domains in as much as they have permeated the law and legal governance environmental discourse. Possible explanations for why, even when scientific facts are presented so clearly to us, our response remains so faint-heartedly - until, as with COVID-19, it 'smacks us in the face'; while even then, as said, some remain skeptical. And, of course, after discussing the human tragedies, I will move on to discuss (in section 4.) what approaches could be helpful to overcome or best handle these factors. More particularly, what legally supported institutional settings and perspectives could be helpful. As said, not so much in terms of specific public policies, but rather on aspects of knowledge generation and dissemination, systemic or integrated governance approaches, and a substantive institutional narrative for action.

\section{Highlighting three human tragedies}

So, why do we fail to understand or fail to act upon our understanding of critical crises and challenges? Rhetorically speaking: why can we not look ourselves in the eyes and do the responsible thing? In this contribution I want to point at three tragic conditions of 
humankind; conditions that may well be at play in not acting rationally in the face of major threats. The tragedies of not properly managing our commons, of not looking beyond our horizon, and of being 'trapped' by cognitive ambiguity. ${ }^{5}$

\subsection{Tragedy of the commons}

Most readers will at least have heard about this first 'tragedy', if only through the title of Garrett Hardin's seminal article, "Tragedy of the Commons" [16], and/or reference to the common pool natural pastures close to traditional English country villages; open to all and used by local farmers to have their cattle graze until depletion of the resource. In Hardin's words: "Therein is the tragedy. Each man is locked into a system that compels him to increase his herd without limit - in a world that is limited. Ruin is the destination toward which all men rush, each pursuing his own best interest in a society that believes in the freedom of the commons. "Hardin points at how this tragedy also applies to pollution, when costs of purifying an operator's waste are higher than those of discharging these wastes into a commons. And so, acting as "independent, rational, free-enterprisers", ultimately leads to collectively "fouling our own nest" [16]. The same reasoning applies to exhaustion of natural resources, as in the example of maritime fisheries, upon the combination of the view that the 'freedom of the seas' serves as a common pool, and of the belief that this common pool presents 'inexhaustible resources of the oceans', which ultimately leads to a risk of extinction of the relevant natural fish stocks - or phrased less anthropocentrically and more ecocentrically, of unique maritime species - with chances at a cascading effect of further biodiversity degradation to follow.

In response to Hardin's call for 'coercive rules or taxing devices', to curb individual rationality in favor of collective rationality in the use of commons, many authors have insisted that Hardin speaks of 'commons' where he should have spoken of 'open access' [17]. While this use of the word 'commons' seems metaphoric, in reference to the potentially tragic practice in the aforementioned English village pastures, indeed it may be said that analytically speaking we should separate private, public/state and common property to come with property rights' incentives and rules of use, while 'open access' is about goods and resources outside of property regimes. The crucial element in the reasoning about the tragedy of the commons is that in such open access areas there exists no ownership control over the resource, such as to protect the environment against pollution and exhaustion. Neither by exclusion from the resource, nor by having any price to pay in compensating an owner for rivalrous or subtractive use. The harm caused by unfettered use of commons, such as to the quality of the environment, ultimately not only pollutes or depletes the resource for those using this for free (or at least making short-term savings), but also causes a 'negative externality' (or 'negative spillover effect'), bringing costs or losses to third parties (if only, potential future users). We witness such externalities already in how the costs of reducing GHGs (especially of $\mathrm{CO}_{2}$ ) are not usually included in the purchasing price of cars or the price of car fuels. So, again, harm caused by situations of individual rationality (i.e., buying without paying for pollution), leading to collective irrationality.

As said, coercive regulation, is usually seen as the proper response to avoid tragedy of the commons' types of situations from occurring, by institutionalizing control and thereby internalizing collective costs. Such regulation may be based upon constitutionally granted legal powers or upon relevant resources being considered as public property. In either case, government regulation may, by representing the public interest and taking stewardship over vulnerable and voiceless interests in that resource, ensure that collective rationality has priority over individual rationality.

\subsection{Tragedy of the horizon}

The collective irrationality of the 'tragedy of the commons' often becomes manifest in that individually we do not foresee how a process of many small negative impacts adds-up gradually, whereby harm to or loss of resources only becomes clear over time and/or in a faraway place. This points at another 'tragedy' that humans face with threats such as pandemics and environmental degradation: negative effects often only reveal themselves in the long run and/or (only or mostly) in faraway places. The tragedy of the horizon poses a challenge that follows from what seem short-term and/or nearby successes, which ultimately amount to long-term and/or at a distance failures. Cumulative effects over time and space are not always ab initio clear to the inventor, investor, producer or consumer, and for that matter, not even to a government with fitting regulatory powers. All too often, a lack of proper understanding of the complexity of the functioning of processes within socio-ecological, -economic and technological systems stands in the way of recognition of long-term and far-away consequences of our actions.

The role of spatial- and timescales in environmental threats, such as pollution, exhaustion and nuisance, is well-known. ${ }^{6}$ Such as in the historic perspective of how environmental problems have evolved from prehistoric to present-day proportions: initially being a matter between private neighbors, then becoming public but still very local (e.g., at village or city level), moving to a regional level (e.g. smoke from factories across villages), to the fluvial level (i.e., pollution of rivers, riverbeds and adjoining lands; possibly across some countries), to continental levels (e.g., acid rain, nuclear accidents; certainly involving multiple nations), and ultimately to the global level (e.g., climate change and

\footnotetext{
${ }^{5}$ In my oral keynote I spoke of 'epistemic tragedy'. The tragedy remains, but I decided to rename its object as 'cognitive ambiguity', to better express that it is not only about how we may know ('episteme'), but also how we act upon what we know (also about what we do not know).
} 
biodiversity degradation). With this gradual upscaling and accumulation, because small scale problems remain as large-scale problems are added - not only do we face greater governance complexity as larger-scale issues call for multi-actor and multi-level policy approaches, but also do we risk an increase in the related issue timeframe. Environmental timeframes stretch from first causation, through to first effects, recognition of effects, acknowledgement of causes, first suggested solutions, policy formulation, policy implementation, first policy effects to, hopefully a final solution. ${ }^{7}$ For large-scale problems such as of $\mathrm{CO}_{2}$-pollution, the timeframe meanwhile already spans centuries, and may still take many decades and even centuries before the issue is solved [18]. On top of that, in as much as causation, recognition and action relate to the emergence of new technologies, following the introduction of larger and more complex industrial processes and outputs, involving new types of substances, devices, products and wastes, the Collingridge dilemma [19] slows-down effective policymaking, thus exacerbating the so-called 'pacing problem' [20]. The pacing problem is about how the pace of newly emerging technologies is much higher than that of regulation providing fitting rules to match either by constraining or facilitating new technologydriven practices. ${ }^{8}$ The dilemma poses a 'double-blind' problem: a rapid regulatory response to new technologies is hampered by the information problem of lacking knowledge about effects of these technologies (i.e., challenging policy-effectiveness, proportionality and fairness), while delaying regulatory response until all/most relevant effects are known, hampers policy formulation and implementation as the technology will already have become entrenched and intertwined with opposing socio-economic interests.

In 2015, Mark Carney was one of the first public figures (as the then governor of the Bank of England) to speak publicly about the 'tragedy of the horizon'. He introduced the theme by stating that "Many of the changes in our world since the 1950s are without precedent: not merely over decades but over millennia.", and that, "(..) the catastrophic impacts of climate change will be felt beyond the traditional horizons of most actors - imposing a cost on future generations that the current generation has no direct incentive to fix." [5]. Basically, again we face a mixture of ability and willingness to know about and understand complex or elongated causal chains in their negative effects over large distances and over long periods of time.

Part of the problem, regardless of whether as ability of willingness to understand, relates to how many humans struggle to comprehend exponential functions, and mostly think linearly and thus underestimate the acceleration pace; the so-called 'exponential growth bias' [21]. As demonstrated with the R-number (for reproduction-rate) in the COVID-19 pandemic, where it seems that without interventions (and $\mathrm{R}$ rising above 1.0) cases may double every three to four days [22]. Exponential gradual processes may also come with unexpected 'tipping points' - more dramatically described as 'points of no-return' - as in the 'hockeystick' graph of global warming. Once some process parameters move beyond certain thresholds, such as of temperatures, small, negligible changes may suddenly come with dramatic consequences. The decline rate of the Antarctic ice sheet is a case in point [4]. While the Arctic waters are already about $1.1^{\circ} \mathrm{C}$ warmer than in pre-industrial times, which already brings gradual degradation, once the temperature rises to $+2{ }^{\circ} \mathrm{C}$, this is expected to cause a much more serious and long-term partial collapse due to ice sheet instability. The longterm aspect of this, not only relates to the acceleration of breaking up and melting of ice, but also to the phenomenon of 'hysteresis', which in this example means that once melted, it would take getting to a $3{ }^{\circ} \mathrm{C}$ below pre-industrial levels temperature to start regaining Arctic ice-formation [23].

Again, these are aggravating aspects to the bare and brute fact of certain actions only having long-term or faraway consequences, beyond the time/space horizon of causer, or indeed, as Mark Carney put it, beyond the time frames of the average business and political cycle. And also, beyond the horizon of technocratic authorities [5] - to say nothing of that of individuals and local communities. So, indeed, with incentives beyond professional or political mandates, and beyond the scope of private interests. Even though, over time, making early adjustments will mean less costly adjustments [5] - to say nothing of the, "upward trend in losses that arise indirectly through second-order events like the disruption of global supply chains." [5], including unforeseen costs through 3rd party liability risks; if those who suffered damage can show that responsible actors failed in mitigating risks or damage - let alone when they acted in violation of relevant legal requirements [5]. So, if only from the financial perspective: "The more we invest with foresight; the less we will regret in hindsight." [5].

In respect of financial concerns, Carney points out that insurers have in fact already acted upon scientific warnings about climate change in conjunction with the brute fact that number of 'registered weather-related loss events' have tripled since the eighties, and related 'inflation-adjusted insurance losses' “(..) have increased from an annual average of around \$10bn in the 1980s to around \$50bn over the past decade." [5]. And as Lunnon said [15], referring to lessons we should

\footnotetext{
${ }^{6}$ My own first understanding of this stems from a report from the Dutch National Institute for Public Health and the Environment (RIVM), published already in 1988 [18].

${ }^{7}$ To add more nuance, I allowed myself to deviate from the RIVM report [18], mentioned in the previous footnote, as this only names 3 time-scales: lead time, regulation time, recovery time.

${ }^{8}$ While I see the drawbacks of law adapting too slow, I also think that law, as in making legal arrangements, should not be called upon before there is a clear need to no longer rely on informal practices, as these are known or expected to be likely to fail in aiding to reach desired outcomes - or avoid undesired ones. To legally formalize behaviour should not be a first instinct, but rather a reflection upon what is proven or likely not to work well.
} 
learn from our "(..) our lack of planning and resilience to Covid": "By refusing to invest in minimising the risk, the required emergency response has cost us so much more, has hit the most vulnerable the hardest and is likely to have huge non-linear impacts on our society via a global depression."

It seems that although, with regards to the pandemic and climate change risk, experts did break the horizon by consistently warning, over many decades, about what could happen, "the world is ill-equipped to prevent or mitigate for either." [15]. Thus, the tragedy of the horizon seems to rather be a political and behavioral problem than one of science experts. And as to the COVID-19 crisis, once it did present itself, it did pose, again in Lunnon's words, "an immediate discrete and discernible danger", whereas the climate change risks are "gradual, cumulative and distributed" [15]. So, again, this begs the question if politicians and citizens can learn a lesson from the COVID-19 pandemic for dealing with the climate change threat. Or, as John Barry recently put it, with some underlying pessimism [24]: "Why is it that our political leaders listen to and make decisions informed by the science in the case of coronavirus - closing schools, restricting travel, putting in place financial support for furloughed workers - but not when it comes to the planetary emergency?" And, from a legal position, one may add the question, why the 'precautionary principle' or indeed the principles of 'intra-generational' and 'inter-generational equity', while so clearly out to break through the horizon, do so little in providing sufficient legal or political justification for legislators and regulators to avoid 'false negatives' and 'underregulation'.9

\subsection{The tragedy of cognitive ambiguity}

While part of the answer to Barry's question remains that indeed Climate change unfolds in a 'gradual, cumulative and distributed' way, there is also the aspect that even when they unfold in sudden events such as droughts, torrential rains, bushfire crises, severe hurricanes, and species extinction, there remains room for discussion about their exact causes, and of course also about how individuals and groups may indeed choose to ignore facts or predictions, and shift the burden of taking action to those seen as more blameworthy and/or more appropriately equipped for success.

This then leads us to a third tragedy, of a more epistemic nature, in how society, communities, organizations and individuals fail in addressing the fact of our failings, or acting upon the awareness of such failings, such as in climate change and biodiversity degradation. While basically the technology is there, although perhaps not as a silver bullet [27], and most likely not without considerable cost,${ }^{10}$ there is reluctance in taking expert insights into the (roots of the) problem, or the (need for) solutions seriously, and move to act upon them.

Perhaps, in part, this reluctance goes back to, or is justified by how within epistemology, as the philosophy of science, verification has given way to falsification. While repetitive verification (as 'inductive inferences') may add to a stronger conviction that a theory probably truthfully represents reality, in an adequate and accurate way, ultimately the possibility remains that one new observation leads to conclude that a theory is (plain) wrong, or has a far more limited claim to truth-value, than initially proclaimed. ${ }^{11}$ And so, the work of science should rather be seen as a useful means to eradicate falsehoods, than to reveal ultimate truths, and 'theories' should only be seen as 'scientific' when they (implicitly) come accompanied with causal statements suitable to be refuted when confronted with empirical observations. In this sense the concept of an 'absolute scientific truth' is an oxymoron. Then again, it has to be said that even 'falsification' is criticized, because observations whereby theories may be tested will in turn be presented in statements that reflect theoretical assumptions which in themselves may be refuted, and so falsification seems to 'boil down' to theories being tested against each other; ending in a regressus ad infinitum [31]. To Popper, this could be resolved by reaching scientific consensus about the truth-value of certain, 'basic statements', as a matter of being "satisfied for the time being" [32-33] - as these basic statements are of a kind "(...) that is especially easy to test. For it means that we are stopping at statements about whose acceptance or rejection the various investigators are likely to reach agreement." [32]. In opposition to Popper's normative statement about how science should be practiced, Kuhn has offered a descriptive approach of how science is in fact practiced [33]. In his description the concept of scientific paradigms features as the cognitive and social 'picture' or 'assemblage' of models, concepts, metaphors, and exemplars that express the leading scientific thought/understanding. They can be seen to point at the epistemic values that lead theory-choice and may be said to clarify considerations behind Popper's notion of generally accepted basic statements. Only statements that follow from theories that have not been falsified and which stand strong in terms of epistemic values such as 'predictive accuracy', 'internal coherence'. 'external consistency', 'unifying power' and 'fertility' and 'simplicity' [31], qualify as 'basic'. Still, the social relevance of such values in deciding the future course of scientific endeavor underscores the intersubjective element in the scientific discourse.

All this being said, popular understanding of this state of epistemic endeavor, may explain the sometimes

\footnotetext{
${ }^{9}$ See David Vogel's seminal paper [25], and for a basic introduction to the named principles, Ellen Hey [26], esp. paras 4.5 and 4.6 .

${ }^{10}$ Although it is said that for example the energy transition also holds opportunities for economic growth and employment [28].

${ }^{11}$ The latter not being unusual, particularly at early stages of theory development, as was well-expressed by Imre Lakatos:

“All theories (...) are born refuted and die refuted.” Reference [29] from Stanford Encyclopedia of Philosophy [30].
} 
overly relativistic, in fact skeptical appreciation of science. In 'postmodernism' we see an epistemic strand which argues that there simply is no absolute and/or objective knowledge about reality, but only relative and/or intersubjective knowledge. In other words, we can achieve no more than a 'constructivist' understanding of the world, shaped by our sociopsychological perceptions, assumptions and needs. In the words of Charles Colson: "(..) there is no objective universal truth; there is only the perspective of the group..."; there are only, "social constructions shaped by class, gender, and ethnicity." [34]. The constructivist element expresses how our understanding of reality is formed (i.e., constructed) through our interactions, and particularly the interactions within the scientific community, which develops mental constructs of a natural reality which is understood to exist outside or independent of human perception, but which cannot be understood objectively.

At times it seems as if a considerable amount of people regards scientific (predictive) statements (such as on the pandemic or climate change threat) to merely reveal 'shared opinions', and that one may choose to take these more or less seriously, and to which a rejection with counter statements does not in turn require a similar measure of scientific rigor. Still, while there is an epistemic tragedy in our inability to reveal ultimate truths, this has not stood in the way of an increased scientific understanding of our world and puzzle-solving and engineering ability to improve elements of the world in our perceived favor [33]. The tragedy of cognitive ambiguity is one that originates in the 'cognitive fallacy' of scientific over-expectation and a subsequent overly relativist appreciation of the fruits of scientific exploration.

An extreme expression of this follows the wave of populist thought and populist politics that has gained traction over the last 20 years. Under such populism, scientific knowledge is not just criticized, as it should be, but downright rejected as product of elites driven by non-epistemic (political, moral, social or religious) values [31] - cynically placing wisdom of the people (of not a people) against the so-called expert views of a corrupt and conspiring elite. And with that, institutionalized forms of knowledge-generation, such as in universities, of knowledge-representation, such as the UN IPCC panel for climate change, or the WHO, and of knowledge-use, such as by government when restricting behavior to stop COVID-19 contamination, are prima faci regarded with distrust - as is demonstrated by the introduction of terms such as 'fake news', 'alternative facts', and 'partial truths'. ${ }^{12}$ Some even speak of 'the death of expertise', rhetorically addressing the decline in expert authority, partly as a consequence of higher education weariness on upholding quality standards, but also due to how internet and social media facilitate anti-expertise and antiintellectual thinking. As Nichols [33] puts it: "These are dangerous times. Never have so many people had access to so much knowledge, and yet been so resistant to learning anything. ". 13

Recently, Robbert Dijkgraaf, the current director of the Princeton University for Advanced Studies, raised the question, in his column for the Dutch NRC newspaper [39], ${ }^{14}$ if we should conclude that we have taken skepticism too far.

He testifies that his hopes were that one of the few positive side-effects of the current pandemic would be that of a renewed respect for science, now that our health is in the hands of experts, and that this regained respect would also be helpful in dealing with other major problems, such as climate change. But alas, instead of more respect, we are confronted with 'corona skeptics'. Perhaps, he wonders, we have taken the image of science as 'organized skepticism' too far. While there is merit in the role of 'cross-thinkers' in science, of 'the scientist as rebel', who boldly takes on dogmas and bravely states that 'the emperor wears no clothes', too easily the image of the heroism of 'unsung geniuses' leads to taking scientific disregard or disqualification as a sign of genius. But in fact, cross-thinkers are usually wrong, which is why we call them cross-thinkers. Dijkgraaf reminds us that most scientific breakthroughs take place within the established order, and that research is usually a matter of 'business as usual', but just a bit better or different. And that such labor usually involves small steps, building upon existing work, adding new pieces to the jigsaw puzzle instead of wiping the puzzle off the table - much alike Kuhn's picture of puzzlesolving as the normal business of science [33]. Dijkgraaf concludes by stating that given the dependency of modern society on science and technology, there should be a better understanding of the 'internal process' of science, as the 'refined interior of the knowledge machine', and more "respect for the fact that the material of science is the truth."

As a final reflection on the tragedy of cognitive ambivalence, allow me to (merely) point at the role of human nature in terms of emotions involved in our decision on whether or not to act upon accepted knowledge, and if so, how. Even if we do not take issue with scientific rigor behind expert statements, we all too often fail in following up. Many may now think of the famous David Hume quote (of 1739) that "Reason is, and ought only to be the slave of the passions, and can never pretend to any other office than to serve and obey them.", which summarizes his claim "that reason alone can never be a motive to any action of the will; and secondly, that it can never oppose passion in the direction of the will." [40]. If one already believes that

\footnotetext{
${ }^{12}$ Meanwhile, the WHO has a page on its COVID-19 website inviting to report on misinformation about the virus [35], and make no mistake, similar to today's protests were also voice in 1918-1919 San Francisco, during the months of the Spanish flue [36].

${ }^{13}$ What also does not help are deliberate campaigns by industry to merely out of self-interest, shed doubts about statements regarding health and environmental treats. For an impression see: Oreskes, Naomi, and Erik M. Conway (2010) [38].

${ }^{14}$ I have translated some of Dijkgraaf's writing from Dutch into English, sometimes paraphrasing, sometimes translating literally but without using quotation marks as this would suggest his approval with my phrasing.
} 
the idea of global warming is a hoax, then one will be less likely to deem the arguments in support of investing in wind parks credible. ${ }^{15}$

Peter Drahos speaks of the "Contextual fallibility of rationality" [42]; not being optimistic about human rationality, such as in the face of 'mounting evidence', to "eventually overcome emotional commitments fuelled by false world views.", adding that, "The emotional genesis of beliefs (Not necessarily of a religious nature) is a less comforting hypothesis because emotion may so suffuse an actor's world view that no amount of contrary evidence will change an actor's beliefs. " [42]. He names the NRA's (US National Rifle Association) stance on gun control ('Guns don't kill people, people kill people.'), and the belief that some people(s) hold in the curative powers of a Rhino horn, and wonders if, "In $a$ world where truth is not a self-executing regulatory tool of persuasion (...) we return to the pre-Socratic traditions of rhetoric to influence emotion and therefore outcomes?" and in conclusion writes that nowadays these techniques, "(..) are practised on digital media at a speed and scale unimaginable to the rhetoricians of Ancient Greece. Social media, as Peter Grabosky (2016) has argued, has made the use of ridicule an even more potent form of regulation." [42].

And so, it remains a big question if we are able to learn from crises, such as that of COVID-19, to improve acting upon knowing what is best for us. In a recent webinar about the 'Energy transition after COVID-19' organized by Delft University in the Netherlands [43] dr. Gerdien de Vries, a climate psychologist, argued that we have little cause for optimism, referring to several reasons why 'being green may not be that easy after COVID-19'. Those reasons involve: 1 . that we may have developed 'not so green behavior' during COVID19 , such as being 'lazy around the house', with higher energy consumption, and less willingness to separate our wastes; 2 . that we have reprioritized our values, such as buying ( $2^{\text {nd }}$ hand) cars instead of using public transport; 3. that we display 'reactance', as a form of psychological resistance against orders and undesired recommendations; 4. that having followed orders (e.g., social distancing) we are next 'morally licensed' to be more relaxed, as if we now deserve a treat in another sphere, such as that of climate change.

So, we may summarize the tragedy of cognitive ambivalence by concluding that scientific knowledge ultimately remains uncertain, expert-knowledge is increasingly been rejected (as serving elitist interests only), emotions have priority over cognition, and psychologically COVID-19 may not have taught us the desired lesson to next act on ecological sustainability.

With that, and with the earlier conclusions on the tragedies of the commons and of the horizon in mind, I will now move to consider what remedies we may develop to overcome all three tragedies, or at least improve our chances of not falling victim to them, and having a better chance of addressing future threats, such as following climate change and biodiversity degradation. This I will look into in section 4. of this contribution.

\section{Handling tragedies - three institutional safeguards}

The challenges to a sustainable and healthy, pandemic resilient and clean environment, together with tragic limitations in human understanding and rational behavior, call upon our wisdom to act upon what we do know and upon our awareness of limitations in our knowledge or willingness to act upon these limitations.

In this section of my contribution, I will look especially at what approaches could be helpful to overcome or best deal with these impeding factors, particularly from a legal governance perspective, of legally supported institutional settings and perspectives. At that I will address the aspect of institutional safeguards for proper knowledge generation and dissemination, for systemic and integrated policy approaches, a substantive institutional narrative for action, and societal resilience. The reader should keep in mind that the below suggestions are just that, and rather an agenda for further research, than a conclusive statement about forward action.

My inspiration for institutional safeguards follows from two examples of such safeguards, in very different areas.

Firstly, in a broad institutional sense, very much responding to human failings, in James Madison's reasoning behind the doctrine of the 'separation of powers' [44]. Briefly, the concept of separation of powers and of checks \& balances regarding state government is one where it was understood that putting the powers of legislation, administration and jurisdiction in one hand may be efficient, effective and fair when this is the hand of a king-philosopher, but such persons seem (almost?) impossible to find and so the strategy of all government powers in one hand seems (statistically) misadvised. In the Federalist paper no. 51, one of the US founding fathers, James Madison, eloquently reasons from human failings to human wisdom in securing a separation of powers: "But what is government itself, but the greatest of all reflections on human nature? If Men were angels, no government would be necessary. If angels were to govern men, neither external nor internal controls on government would be necessary. In framing a government which is to be administered by men over men, the great difficulty lies in this: you must first enable the government to control the governed; and the next place, oblige it to control itself. A dependence on the people is, no doubt, the primary control on the government; but experience has taught mankind the necessity of auxiliary precautions." [44].

And so, while it makes government less efficient, the separation of powers expresses the 'institutionalized' wisdom that humans are not angels and that not only do we need a government, we also need its powers to be divided to avoid a (wicked) dictatorship; the controls over itself being the mechanisms of checks $\&$ balances that exist to keep the separated powers at bay. In the same vein, our challenge is to secure institutional arrangements that make us aware of the tragic conditions in our efforts to do 'planetary good' and

15 This latter example is taken from Bas Heine [41]. 
circumvent the obstacles that these pose to our actions, so as to do 'the responsible thing' - while retaining citizens engagement in the process.

A second institutional inspiration is of a more operational nature, as witnessed in the practice of insuring against risks of harm and to vaccinate against the risk of disease. At some stage of the history of modern (welfare) societies, actors of state, civil society networks and markets, separately and/or jointly acted upon the notion that it made sense to make collective precautions in respect of serious risks, as a matter of prospective/pro-active action, to lower such risks, or reduce the harm that they could bring if their occurrence could not be avoided.

To have (legal) arrangements in place to provide (periodical) vaccinations is a typical example of investing upfront, to avoid or lower the cost that would otherwise ensue should the disease strike - much along the line of the above statements in Mark Carney's speech. The same applies to his statements about the societal importance of proper insurance schemes: "Insurance supports households, companies and investors, safeguarding them from perils they could not otherwise shoulder. It matches long-term savings and investment, financing the infrastructure essential to productivity." And so today, insurance plays a major part as "Alongside major technological, demographic and political shifts, our very world is changing. Shifts in our climate bring potentially profound implications for insurers, financial stability and the economy." [5]. When expert statements warn about risks on or beyond the horizon, following first (bits of) evidence, even when uncertain and tentative about the chances at and the magnitude of these risks, insurance facilities may form a first buffer to hopefully cope when disaster strikes, and perhaps to transition or steer human endeavor away from risky behavior.

In both examples the underlying idea is to steer ourselves away from the short-term, selfish or downright short-sighted, behavior, to institutionally move beyond the tragedies that otherwise may withhold us form taking appropriate action while we still can.

\subsection{Institutional arrangements for knowledge generation and dissemination}

To start, while hoping that the point is so obvious that it hardly needs arguing for, I want to emphasize very broadly the need to, also legally, secure and nourish proper knowledge infrastructures. It may be said that knowledge is a 'public good', being non-rivalrous (i.e., my knowledge of something does not stand in the way of others knowing about the same) and not-excludable (i.e., it being difficult to restrict others from enjoying the benefits of that knowledge), but this is not to say it does not require taking care of. Aside from the fact that especially non-excludability is seen to sometimes suffer from being 'privatized', such as by intellectual property rights (e.g., copyright and patent), I hope to have sufficiently made the point, in the above, that as a public good, to indeed be enjoyed by all, it is vulnerable in being susceptible to misrepresentation. We do need institutional arrangements to facilitate and protect proper generation, independent quality, access, valorization and dissemination of knowledge. Through a system of schools and universities, fostering education and research, but also when it comes establishing and maintaining independent and impartial expert agencies and/or epistemic communities that can collect and reflect upon and report about the state of the art knowledge in knowledge dependent areas, such as that of a sustainable and healthy environment. ${ }^{16}$ To secure that their staffs and members are well facilitated and, if necessary, protected, and that their findings are made public and open for debate. I think, for example, about national institutes for public health and the environment, but equally about the UN IPCC or the WHO. With all of this comes the importance to arrange for mechanisms of critical peer-to-peer review and inclusion of what is nowadays known as a 'citizen science' perspective, in the sense of public participation - whereby the agenda of research and teaching is more clearly related to challenges that citizens experience.

Somewhat related to the latter, I believe it to be crucial that (legal arrangements exist that enable) NGO engagement, such as by allowing engaged societal NGOs, to build-up knowledge and have the opportunity to request, if need be through legal action in an independent, impartial and decisive court of law, openness of information, to be involved in public participation, and to have access to an independent and impartial court in a case against government and against private companies. What recently happened in the Netherlands, where the state government was convicted by the supreme court of the Netherlands to ensure that it would live-up to its promise to by the end of 2020 reduce CO2 emissions by $25 \%$ compared to 1990 levels, is the kind of active, if not activist legal approach that is much needed to trigger public debate and call relevant actors into action [45]. Similarly, a Dutch NGO case was recently brought against Royal Dutch Shell, on the issue of its purportedly continued and excessive $\mathrm{CO}_{2}$ emissions [42]. Enhancing NGO involvement in the climate change and biodiversity degradation debate, opens possibilities for improving openness of information and sharing and opposing expert opinions on these challenging issues.

In more operational terms, I deem it of critical importance that binding legal provisions exist for environmental impact assessments, both at strategic and operational level. Operational, to address specific activities that have the expected potential of bringing

\footnotetext{
${ }^{16}$ Needless to say that international (legal) cooperation is vital, not only when it comes to meeting the scale-level of problems of climate change and biodiversity degradation, as these are global issues, but also to create opportunities for developing world-wide knowledge generation and supporting infrastructures such as of WHO and UNEP - in conjunction with many informal, public-public, public-private and private-private transnational forms of cooperation, such as in these so-called 'epistemic communities', such as the IUCN.
} 
serious harm to the environment. Strategic, because we also need to have assessments about the general direction when it comes to, for example, our energy strategy or our waste-management or circularity strategy - including not only cumulative faraway and long-term impacts, but also expressing our uncertainties about them, and to not only look at the environment from the perspective of ecological sustainability, but also that of public health. Crucially, of course, such provisions need to include opportunities for learning, through longitudinal evaluations.

\subsection{Institutional arrangements to embed desired narratives}

Having formal institutional arrangements in place is one, but we also need to institutionally provide an intrinsic direction - perhaps even a 'narrative' that provides a positive stimulus or momentum for collective action, as a shared perspective amongst many. We know how religion and patriotism can present a strong conviction or motivation to prioritise certain values and act in accordance with their intrinsic appeal - to perhaps link to our subject as stewardship over the earth's resources, protection of national heritage, and solidarity across generations. Yet another example is that of the 17 UN Sustainable Development Goals [47], which inter alia serve as focal points for awareness, action, policymaking and capacity building.

As a lawyer, knowing full-well that law is mostly there to avoid and remedy social failure in informally handling or avoiding injustice and promoting justice, I still have my hopes that certain fundamental legal rights and principles can serve to ignite enthusiasm as a matter of 'just ambitions'. A legal take as a call similar to what I saw on a protest sign: "Ask not what your planet can do for you, but ask what you can do for your planet". This is not the place to elaborate, but I consider the following legal principles and rights to be especially significant to raise awareness and operate as a call for action. While placing principle of 'sustainable development' center-stage (i.e., 'Humans are entitled to a healthy and productive life in harmony with nature.' principle 1, Rio-declaration 1992)[48], several related principles are equally relevant to providing commanding guidance, such as those of: 'intergenerational equity' (i.e., 'The right to development must be fulfilled so as to equally meet developmental and environmental needs of present and future generations.' - principle 3, Rio-declaration 1992)[48], 'intra-generational equity' (i.e., Rio-principle 3, cited earlier, and 6: 'The special situation and needs of developing countries, particularly the least developed and most environmentally vulnerable, shall be given special priority (...)' [48], 'precaution' (i.e., 'In order to protect the environment, the precautionary approach shall be widely applied by States according to their capabilities. Where there are threats of serious or irreversible damage, lack of full scientific certainty shall not be used as a reason for postponing cost-effective measures to prevent environmental degradation.' principle 15, Rio-declaration 1992) [48] and 'prevention' (i.e., '(...) the responsibility to ensure that activities within their (...) control do not cause damage to the environment (..)' - principle 2, Rio-declaration 1992) [48]. To add a 'bite', one may also refer to the 'polluter pays' principle (i.e., 'National authorities should endeavour to promote the internalization of environmental costs and the use of economic instruments, taking into account the approach that the polluter should, in principle, bear the cost of pollution, with due regard to the public interest and without distorting international trade and investment.' principle 16, Rio-declaration 1992) [48]. This principle is also often referred to in support of the mechanism of 'Extended Producer Liability' (EPR). In the words of the OECD, EPR “(...) is a policy approach under which producers are given a significant responsibility financial and/or physical - for the treatment or disposal of post-consumer products. Assigning such responsibility could in principle provide incentives to prevent wastes at the source, promote product design for the environment and support the achievement of public recycling and materials management goals." [49]. In this perspective it could be argued, as by one of the IPCC-members during a seminar at Exeter University UK in early summer $2017,{ }^{17}$ that oilcompanies cannot escape responsibility, and even liability, for $\mathrm{CO} 2$ emissions merely on the basis of saying that it is their customers' behavior that caused these emissions.

These (and related) principles should become more leading and appealing, not only in the legal discourse, but also in public debate. At which, of course, the precautionary principle has special relevance in the context of the tragedy of the horizon; even if our knowledge is uncertain, this should not keep us from taking cost-effective measures to avoid irreversible or serious environmental harm from happening.

A similar statement could be made as regards basic human rights, such as of: a clean environment, (access to) clean water, clean energy and (access to) public health. These should not merely be 'social rights' expressing only a non-enforceable duty of government, but function as 'positive obligations', denoting that, as it reads for example in Article 1 of the European Convention on Human Rights [50], states, “(...) shall secure to everyone within their jurisdiction the rights and freedoms defined in section 1 of this convention." a section which includes, inter alia, the right to life (Article 2 ECHR), to bodily integrity (Articles 2 and 3 ECHR), to liberty and security (Article 5 ECHR), to a fair trial (Article $6 \mathrm{ECHR}$ ), and to respect for private and family life (Article 8 ECHR).

Finally, fitting the stewardship narrative, interesting initiatives have been taken in the sphere of 'rights of nature', to create legal protection, such as legal immunity and accompanying claim rights against infringement, by granting (some form of) legal

\footnotetext{
${ }^{17}$ Attended by this author, but not officially documented, while the name of the panel-member also did not stick in memory.
} 
personality to objects or species of nature - animal, plant, fluvial, natural habitats. It is a subject that was put to the environmental lawyers' attention already in the nineteen-seventies, by Christopher Stone [51], and which has meanwhile gained traction, [52-53] inter alia supported by the Global Alliance for the rights of nature [54]. Perhaps the acknowledgement of such rights, however limited in scope, can help to create greater awareness about and more forceful action against projects that add to biodiversity degradation. As a legal scholar, I have to say here that aside from legislative and treaty recognition of such rights, again, an active role of courts (and of the aforementioned NGOs) may be crucial in supporting this new intrinsic momentum. And, of course, ultimately to grant rights to nature can function, firstly, as a way of establishing specific rights in what we may, literally, see as elements of our commons, and secondly, a way of giving voice to interests which stretch beyond the horizon of our human lifespan.

\subsection{Institutional arrangements towards a systemic approach to environmental resilience}

Lastly, I want to make two brief suggestions promoting a more integrated approach to policies fostering a healthy and sustainable environment. My thinking behind this is that without a more holistic perspective on the environmental challenges that lie ahead - both with respect to a healthy and sustainable planet, and the way these two ambitions are connected (as mentioned in para 2.4) -, our chances to overcome 'tragic obstacles' will diminish due to fragmentation in our understanding and our actions. The ill-effects of the limitations of individual rationality, under the tragedy of the commons, and of our 'business as usual' focus on the here \& now, under the tragedy of the horizon, will exacerbate if not addressed by an encompassing, collective rationality, driven by a forward-looking perspective.

I will name two examples.

Firstly, the circular economy perspective that is about the need for 'closing the loop' by moving away from the linear economy - the 'one-directional' economy of 'taking, making, using, disposing'; from the extraction of natural resources, to production, distribution, consumption and waste, which exhausts resources and causes waste pollution. A circular economy would entail that we reconnect the 'disposing' and the 'taking', by recovering and recycling, or become even more ambitious, as expressed in the 3Rs: reduce (waste), reuse and recycle. Ideally, this would lead to a situation in which ultimately there would no longer be a need for primary resources as we could continue in perpetuity by only using secondary resources, but it would be wonderful to at least move much closer to this ideal state of affairs [55].

The ambition of moving from a linear to a circular economy is a sustainability challenge that is also reflected in some Sustainable Development Goals (SDG), particularly in: SDG12 ('Responsible consumption and production'), to ensure sustainable consumption and production patterns “(...) requires that we urgently reduce our ecological footprint by changing the way we produce and consume goods and resources." [56] (e.g., water-use in agriculture: $70 \%$ of all freshwater) efficient management of resources but also encouraging business and consumers to recycle and reduce waste, and in other SDGs, such as, SDG11 ('Sustainable cities and Communities'), to make cities and human settlements inclusive, safe, resilient and sustainable. “(...) sustainable development cannot be achieved without significantly transforming the way we build and manage our urban spaces." [57] The relationship of SDG11 to circular economy lies in if and how this concept can apply to a particular locus of sociotechnical/ecological systems, of 'mega-cities', especially in the developing world, experiencing rapid growth through rising populations and increasing migration [58].

Already in 2015, the EU also expressed its ambition of 'closing the loop', by bringing out a special action plan on the subject, 'Closing the loop - An EU action plan for the Circular Economy' [59], which meanwhile has a follow-up in the 2020 'New Circular Economy Action Plan' [60]. The latter document starts its introduction by stating: "There is only one planet Earth, yet by 2050, the world will be consuming as if there were three 1. Global consumption of materials such as biomass, fossil fuels, metals and minerals is expected to double in the next forty years 2 , while annual waste generation is projected to increase by $70 \%$ by 2050 3. "18 It relates this new action plan to its European 'Green Deal' initiative, as a 'concerted strategy for a climate-neutral, resource-efficient and competitive economy' [61].

I believe the 'new plan' to be an example of an important next step in furthering the concept of a circular economy, and one that underscores the importance of creating new institutional arrangements, also of legal governance. To move beyond specialization and fragmentation, including negative externalization, in existing linear value-chains - of and beyond supply-chains, including consumption and disposal. And with that, to move from merely ecoefficient to eco-effective practices, to develop an inclusive and meta/long-term perspective on how our economic systems need to change. For example, with respect to the rules of competition law [62], particularly on how the foundations of the competitive market (i.e., increasing consumer welfare and economic growth) and of circularity (i.e., with new circular business models, closing the loop to protect 'people, planet and profit')

\footnotetext{
${ }^{18}$ See earlier reference. The endnotes in this section of the plan refer to: 1. UN-SDG12, 2. OECD (2018), Global Material Resources Outlook to 2060. 3. World Bank (2018), What a Waste 2.0: A Global Snapshot of Solid Waste Management to 2050 .
} 
can be resolved, as well as how to further develop the concept of EPR (as mentioned in section 4.2, to include a full value-chain responsibility). New institutional settings will be vital to develop a systemic circular economy approach that internalizes environmental concerns across value-chains, and in fact across the whole of the economic system, together with extending moral and legal concepts of responsibility and liability of actors within those chains and within that system providing institutional support for broadening the horizon of our private concerns to better include collective interests.I

Secondly, in a similar vein, I simply want to name and emphasize the need to also develop a broader perspective in scientific research and policymaking in terms of developing a (multi-/interdisciplinary) nexus approach connecting concerns across policy domains, such as environment and health, but particularly between different sectors of natural resource management, such as of water, energy and food (the 'WEF nexus'). This, again, can help to move beyond policy silos, and be more likely to look at long-term perspectives and overcome rivalries between sectors. This is not the place to discuss intricacies of opportunities and obstacles of a nexus approach, and if and how "(...) the nexus approach seeks to overcome the current lack of engagement between the systems of provisioning, that is, 'breaking down the silos' (...) to articulate governance practices in different sectors, which have historically been governed quite separately." [63]. My hopes are that we will before long be able to flesh out new systemic approaches which can lead to new supporting institutional settings to balance, in the words of Hamidov and Helming [64], the "(..) benefits and trade-offs across relevant sectors." As "(...) the water-energy-food (WEF) nexus has become an important concept in natural resource management. It has been conceptualized to analyze linkages and trade-offs between the three sectors, across temporal and spatial scales. However, the concept has so far mainly been conceptual, with little empirical evidence or proof of concept in real world cases." And so, my hopes are that indeed such cases can lead to evidencebased knowledge to find a way forward.

\section{Finally - 'Build Back Better' and 'A view from the balcony'}

At the end of this contribution, I want to make two final points; one about the so-called 'Build Back Better' (BBB) adage, and one about taking 'A view from the balcony', with my personal reflection.

\subsection{Build Back Better (BBB)}

In the midst of the COVID-19 pandemic, the Build Back Better (BBB) adage came into focus again, following the idea that once the pandemic is over, probably mostly due to vaccination, recovery from loss and illness, as well as from economic distress, should be organized in a way that will bring short-term recovery benefits, while also being helpful to be better prepared to withstand a possible pandemic recurrence or, when unavoidable, suffer less harm from this, and including concerns about sustainability of our planetary environment.

Under the BBB-adage we should, in the words of Barry [24], “(...) be seeking to (...) and ensure a just and green recovery for the economy and not a return to 'business as usual'." He wonders, somewhat dramatically, if: “(...) the pandemic (has) opened the 'Overton widow' of possible public policy responses so that it is now possible to imagine the end (or radical transformation) of capitalism rather than the end of the world?" [65]. In more neutral terms, Mannakkara and Wilkinson [66] write: "The term "build back better" $(B B B)$ is commonly used to represent an ideal recovery process where physical, social and economic aspects of a community are simultaneously developed to a state of new normalcy which is more resilient than the predisaster setting. "So, the challenge is to be resilient not only by resisting shocks but also by adapting, to indeed 'build back better', so that the same type of shock will not re-occur or will have far less negative impact. Their analysis also addresses the role of law, especially in terms of legislation that should either be facilitative (")...) to simplify and assist recovery activities to speed up the recovery process.") or command compliance (")...) using legislation to enforce recovery initiatives to conform to BBB principles. "). ${ }^{19}$

The UN also takes the BBB concept seriously, as it demonstrated already in its 2017 UNISDR (UN office for disaster risk reduction) report: 'Build Back Better in recovery, rehabilitation and reconstruction' [67]. In this report we read that: "Countries and communities that have faced disaster, can 'build back better', during recovery, rehabilitation and reconstruction, when they have prepared for the risk of this event to happen by actions to strengthen their 'recovery capacity and decision-making effectiveness'." Amongst other recommendations regarding capacity building for resilience it names the making of 'national disaster recovery frameworks' to assist public and private stakeholders, and the importance of instituting or strengthening “(...) policies, laws, and programs that promote (incentivize), guide (ensure), and support Build Back Better (BBB) in Recovery, Rehabilitation, and Reconstruction (RRR) in both the public and private sectors, and by individuals and households. " [67].

To name yet one more global actor, the World Bank has issued various publications and news item, such as the, 2018 report, 'Building Back Better: Achieving Resilience through Stronger, Faster, and More Inclusive Post-Disaster Reconstruction' [68], but also more recent reports that connect recovering from COVID-19 to sustainability, through (country) reports and blogs, such as one titled 'Building back better after COVID-19: How social protection can help countries

\footnotetext{
${ }^{19}$ Mannakkara and Wilkinson [62] name three categories each with 2 key principles of BBB: 1. Risk reduction (Principle 1 - Improvement of structural designs; Principle 2 - Land-use planning), 2. Community recovery (Principle 3 - Social recovery; Principle 4 - Economic recovery), 3. Implementation (Principle 5 - Management of stakeholders; Principle 6 Legislation and regulation).
} 
prepare for the impacts of climate change', which holds the appealing quote: "There is no vaccine coming for climate change. But by focusing on the social protection that vulnerable communities and people need - whether supporting them to deal with the impacts they are already facing today or helping reduce carbon emissions to put a break on global warming governments can help their citizens be better prepared for any shocks that come." [68]. It seems to me that this expresses the need to regard the BBB concept as one that calls for a pro-active approach to 'immediate discrete and discernable dangers', such as the pandemic threat, but also to the 'gradual, cumulative and distributed' risks, such as of climate change [14] and biodiversity degradation.

\section{2 'A view from the balcony}

This is only a modest contribution towards creating awareness about the 'tragedies' that keep us from acting (effectively) to secure a healthy and sustainable environment, and to suggest some institutional arrangements and approaches to handle these. In a way one could say this contribution is about urging us to, as it were, take a view from the balcony, transcending the immediate threats, to stand back and consider how we can arrange to be better prepared to understand threats to the environment, and act upon such understanding. As with Madison's reference to men not being angels, and why this necessitates the institutional response of establishing government and shaping it in a way that recognizes human shortcomings, we should be aware of the tragedies discussed in this contribution and consider the institutional settings that may protect us against being trapped by them.

In my introduction a spoke of an adage that supports my quest in this contribution: 'optimism of will over pessimism of the intellect'. If we treasure our lives (and that of others), then surely, we should have the will to make the necessary arrangements to overcome the challenges that threaten human life, and the life of many other species. Intellectually, I think the tragedies pose a truly serious obstacle to collectively becoming convinced of the need for and to next actually make such arrangements, and chances are that we will leave it too long. Still, as it is not yet too late, it makes sense to argue for action, and perhaps the COVID-19 pandemic, if only because it hit us hard and made clear that we were illprepared, does help to more seriously address the challenges of climate change and biodiversity degradation. As they say, 'Never waste a good crisis', so perhaps we can indeed Build Back Better. Surely, legal governance can assist in making this possible.

Last spring, a former, now retired colleague sent me a mail message about how he and his wife were doing under the first wave of COVID-19. In this message he wrote: "The strange thing is that I always felt that things in this world would change (the changes in the climate, the consequences of the globalization of our living together, the stability of our prosperity, the consequences of the increase in the world's population), but I had thought and hoped that these changes would be so gradual that we would no longer experience the fractures they caused. So that was (..) a bit disappointing ..." My hopes are that we can still 'turn the tables', to move away from a dismal perspective, which one hopes will not happen within their life-time, to a perspective that holds sufficient institutional wisdom to help ourselves hold positive hopes for the future and act upon these. I do believe that true wisdom can only come when we move to 'the balcony' to not ask what our planet can do for us, but to ask what we can do for our planet - to next find that a healthy and sustainable planetary environment can be achieved as a blessing for all the life it inhabits.

\section{Acknowledgement}

The author wants to thank the Universitas Padjadjaran and the organization of the CSS2020 conference for their kind invitation to present a speech at this conference and their offer to have the (elaborated) text of this published in the conference proceedings. The author has no affiliations, nor did he receive any benefits causing a conflict of interest in the writing of this contribution, for which he and he alone is fully responsible.

\section{References}

1. World Health Organization (WHO) (2020). Zoonosis. See: fact-sheets/zoonoses [Accessed, 26 November 2020].

2. Goodreads. See: Goodreads quotes - Gramsci [Accessed, 16 December 2020].

3. IPCC (2014). Climate Change 2014: Synthesis Report. Contribution of Working Groups I, II and III to the Fifth Assessment Report of the Intergovernmental Panel on Climate Change [Core Writing Team, R.K. Pachauri and L.A. Meyer (eds.)]. IPCC, Geneva, Switzerland (151 pp.) See: IPCC-AR5-CC2014 [Accessed, 26 December 2020].

4. UN News (2014), See: UN-Climate change report 2014 [Accessed, 26 November 2020].

5. Mark Carney (2015). Breaking the Tragedy of the Horizon - climate change and financial stability. Speech given by Mark Carney, Governor of the Bank of England Chairman of the Financial Stability Board, Lloyd's of London, 29 September 2015, p. 3-4. Free download from: Bank of England/Carney speech [Accessed, 21 December 2020].

6. UN Environment Program (2020). Global Biodiversity Outlook 5. See: UNEP GBO-5 9 [Accessed, 24 December 2020].

7. UN Decade on Biodiversity (n.d.). Achieving the Aichi Biodiversity Targets by 2020. See: Aichi Biodiversity targets [Accessed, 26 November 2020].

8. World Health Organization (WHO) (2020). WHO Coronavirus Disease (COVID-19) Dashboard. See: 
WHO COVID-19 Dashboard [Accessed, 24 December 2020].

9. World Health Organization (WHO) (2020). WHO Coronavirus Disease (COVID-19) What is COVID19? See: What is COVID-19? [Accessed, 24 December 2020].

10. BBC News (2020). Newsitem 08 December 2020. Covid-19 vaccine: First person receives Pfiser jab in UK. See: BBC-News First vaccination [Accessed, 24 December 2020].

11. Maya Wei-Haas (2020). Why new coronavirus variants 'suddenly arose' in the UK and South Africa. National Geographic, Science: Coronavirus Coverage 23 December 2020. See: National Geographic Covid-19 variants [Accessed, 24 December 2020].

12. IPCC (2019). IPCC Special Report on climate change, desertification, land degradation, sustainable land management, food security, and greenhouse gas fluxes in terrestrial ecosystems. See: ipcc 2019 [Accessed, 26 November 2020].

13. IPBES Workshop on Biodiversity and Pandemics (2020). Workshop report. http://doi.org/. See news report: https://ipbes.net/pandemics [Accessed, 26 November 2020].

14. Extinction Rebellion (n.d.). This is an emergency. See: Extinction rebellion.global [Accessed, 17 December 2020].

15. The Climate Change Project (2020). Interview with Sarah Lunnon, spokesperson and activist, Extinction Rebellion. See: Sarah Lunnon-Post [Accessed, 17 December 2020].

16. Hardin, G. (1968) The Tragedy of the Commons. Science 162 (3859) 1243-1248. See: ScienceHardin [Accessed, 20 December 2020].

17. Environmental Justice (n.d.). Tragedy of the Commons: Hardin's mistake. See: Hardin'smistake [Accessed, 24 December 2020].

18. Rijksinstituut voor Volksgezondheid en Milieu (RIVM) (1988). Zorgen voor morgen: nationale milieuverkenning 1985-2010. The Netherlands Alphen aan den Rijn : Samsom H.D. Tjeenk Willink.

19. D. Collingridge (1982). The Social Control of Technology. New York: St. Martin's Press; London: Pinter) $\underline{\text { ISBN }} \underline{\text { 0-312-73168-X. }}$.

20. Lyria Bennett Moses (2007). Recurring Dilemmas: The Law's Race to Keep up with Technological Change. 2007 U. Ill. J.L. Tech. \& Pol'y 239.

21. BBC-Future (2020). Exponential growth bias: The numerical error behind Covid-19. See: bbc.com/future/exponential-growth-bias [Accessed, 21 December 2020].

22. The Conversation (2020): Coronavirus is growing exponentially - here's what that really means. See: The conversation.com/coronavirus-is-growingexponentially [Accessed, 21 December 2020].

23. NRC newspaper (2020). Antarctica smelt sprongsgewijs. ('Antarctica is melting by leaps and bounds'; only available in Dutch). See:nrc.nl/antarctica-smelt-sprongsgewijs

[Accessed, 21 December 2020].

24. John Barry (2020). This is what a real emergency looks like: What the response to coronavirus can teach us about how we can and need to respond to the planetary emergency. See: Seminar Barry Dec.2020 [Accessed, 21 December 2020].

25. D.J. Vogel, D.J. (2011). The Transatlantic Shift in Health, Safety, and Environmental Risk Regulation, 1960-2010. JPiRG (2011). See: SSRNpapers/DJVogel 2011 [Accessed, 21 December 2020].

26. See Hey, E. (2016). Advanced Introduction to International Environmental Law. Edward Elgar publishing: Cheltenham, UK - Northhampton, MA, USA.

27. BBC News (2020). Climate change: Technology no silver bullet, experts tell PM. See: bbc.com/news/science-environment [Accessed, 21 December 2020].

28. International Renewable Energy Agency (IRENA) (n.d.). Measuring the socio-economic footprint of the energy transition: The role of supply-chains. See: IRENA report 2019 [Accessed, 21 December 2020].

29. John Worral and Gregory Currie (eds.) (1978). Imre Lakatos, The Methodology of scientific research programmes. Philosophical Papers, Vol. 1. Cambridge University Press. Online ISBN: $9780511621123 \quad$ DOI https://doi.org/10.1017/CBO9780511621123.

30. Stanford Encyclopaedia of Philosophy (2016). Imre Lakatos. See: https://plato.stanford.edu/entries/lakatos/ [Accessed, 24 December 2020].

31. E. McMullin, Values in Science (1982). Presidential address. PSA: Proceedings of the Biennial Meeting of the Philosophy of Science Association Vol. 1982, Volume Two: Symposia and Invited Papers (1982), pp. 3-28.

32. K.R. Popper (1959). The Logic of scientific discovery. London: Hutchinson \& Co.

33. Thomas Kuhn (1962). The Structure of Scientific Revolutions. Chicago: University of Chicago press.

34. Charles Colson (2017). The Charles Colson Collection: The Good Life / How Now Shall We Live? Tyndale House Publishers; IL, USA.

35. World Health Organization (2020). See: WHO Myth busters [Accessed, 24 December 2020].

36. Brian Dolan (2020). Unmasking History: Who Was Behind the Anti-Mask League Protests During the 1918 Influenza Epidemic in San Francisco? Perspectives in Medical Humanities (UC Medical Humanities Consortium, May 19, 2020) https://doi.org/10.34947/M7QP4M .

37. Tom Nichols (2017). The Death of Expertise. The Campaign against Established knowledge and Why it Matters. OUP; USA. 
38. Oreskes, Naomi, and Erik M. Conway (2010). Merchants of Doubt. How a handful of scientists obscured the truth on issues from tobacco smoke to global warming. London (UK): Bloomsbury Publishing.

39. Robbert Dijkgraaf (2020). Dwarsdenkers hebben meestal ongelijk. ('Cross-thinkers are usually wrong.' - only available in Dutch). NRC 18 October 2020. See: NRC 16 October 2020 Dijkgraaf [Accessed, 21 December 2020].

40. David Hume (1739). A Treatise of Human Nature. London: John Noon. Also see: A Treatise of Human Nature. [Accessed, 23 December 2020].

41. Bas Heine (2020). Hoe alles een kwestie van perspectief werd. ('How everything became a matter of perspective.' - only available in Dutch) NRC-newspaper 31 January 2020. See: NRCnews/Bas Heine [Accessed, 23 December 2020].

42. Peter Drahos (2017). Regulation, Institutions and networks. In: Peter Drahos, ed. (2017). Regulatory theory: foundations and applications. Acton: ANU Press, 2017, pp. 1-22 DOI: $10.22459 /$ RT.02.2017.01.

43. Social Innovation in the Energy transition (SIET) platform, Delft University of Technology, the Netherlands (2020). Seminar series Energy Transition after covid-19. Wake up call or waiting for the rebound. (With recording). See: TUD-wake up [Accessed, 23 December 2020].

44. Federalist Papers No. 51 (1788). See: Billofrightsinstitute/federalist-no-51 [Accessed, 23 December 2020].

45. Dutch Urgenda-case. See www.urgenda.nl [Accessed, 23 December 2020].

46. Milieudefensie-case. See: Milieudefensie v shell [Accessed, 23 December 2020].

47. UN Sustainable Development Goals. See: UNSDGs [Accessed, 23 December 2020].

48. UN Rio-declaration (1992). See: UN-GA Rio Declaration 1992 [Accessed, 23 December 2020].

49. OECD (n.d.). Extended producer responsibility. See: OECD-EPR [Accessed, 23 December 2020].

50. Council of Europe (1953-2010). European Convention for the protection of Human Rights and Fundamental Freedoms. See: ECHR [Accessed, 23 December 2020].

51. Christopher Stone (1972). 'Should trees have standing? Towards legal rights for natural objects', Southern California Law Review 1972, p. 450-501.

52. Christopher Stone, Should trees have standing? Law mortality, and the environment. New York: Oxford University Press 2010.

53. A. Grear (ed.) (2012). Should trees have standing? 40 years on. Cheltenham: Edward Elgar Publishing 2012.

54. Global Alliance for the rights of nature. See: https://therightsofnature.org/ [Accessed, 23 December 2020].
55. J.R.C. Tieman (2017). Afval of grondstof in een circulaire economie - op zoek naar meer rechtszekerheid. In: Chris Backes, John Tieman \& Natasja Teesing (Eds.), Met recht naar een circulaire economie (pp. 17-64). Boom Juridisch. (Only available in Dutch).

56. UNDP-SDG12 (n.d.). See: UNDP-SDG12 $\underline{\text { Responsible-consumption-and-production }}$ [Accessed, 24 December 2020].

57. UNDP-SDG11 (n.d.). See: UNDP-SDG11 Sustainable-cities-and-communities [Accessed, 24 December 2020].

58. J. Nurdiana, M. Heldeweg, M-L. Franco-García (2019). New lens scenarios to shape the future of Indonesian's first circular city. Contribution to the $4^{\circ}$ Congreso de Ingeniería, Ciencia y Gestión Ambiental AMICA - 5th International Conference of Greening of Industry Network: 28, 29 y 30 de octobre de 2019, Instituto de Ingeniería de la UNAM, Ciudad de México. Ciudad de México: UNAM, Instituto de Ingeniería, p. 523527 ID 617. See: Nurdiana et al. Ciruclar city [Accessed, 24 December 2020].

59. European Commission (2015). Communication from the Commission to the European Parliament, the Council, the European Economic and Social Committee and the Committee of the Regions. Closing the loop - An EU action plan for the Circular Economy. Brussels 1.12.2015; $\operatorname{COM}(2015) 614$ final. See: EU-Closing the loop [Accessed, 24 December 2020].

60. European Commission (2015). Communication from the Commission to the European Parliament, the Council, the European Economic and Social Committee and the Committee of the Regions. A new Circular Economy Action Plan. For a cleaner and more competitive Europe. Brussels 11.3.2020; $\operatorname{COM}(2020) 98$ final. See: A New Circular Economy Action Plan [Accessed, 24 December 2020].

61. European Commission (2019). Communication from the Commission. The European Green Deal. Brussels 11.12.2019; COM(2019) 640 final. See: EU Green Deal [Accessed, 24 December 2020].

62. A. Gerbrandy, A. (2017). Mededingingsrechtelijke consequenties van een Circulaire Economie. In Chris Backes, John Tieman \& Natasja Teesing (Eds.), Met recht naar een circulaire economie (pp. 185-200). Boom Juridisch. (Only available in Dutch).

63. Alberto Matenhauer Urbinatti et al. (2020). 'Opening up'the governance of water-energy-food nexus: Towards ascience-policy-society interface based on hybridity and humility. Science of the Total Environment $744 \quad$ (2020) 140945. https://doi.org/10.1016/j.scitotenv.2020.140945 [Accessed, 24 December 2020].

64. Ahmad Hamidov and Katharina Helming (2020). Sustainability Considerations in Water-EnergyFood Nexus Research in Irrigated Agriculture. 
Sustainability 2020, $12 \quad 6274$ doi: 10.3390/su12156274 (20 pp).

65. Wikipedia (n.d.) Overton window. See: https://en.wikipedia.org/wiki/Overton_window [Accessed, 24 December 2020].

66. Sandeeka Mannakkara and Suzanne Wilkinson (2013). Post-Disaster Legislation for Building Back Better. (2013) Construction Law Journal, Issue 8. P. 495-506.

67. UNISDR (UN office for disaster risk reduction) Build Back Better in recovery, rehabilitation and reconstruction 2017 - consultative version. See: UNISDR-BBB [Accessed, 25 December 2020].

68. Stéphane Hallegatte, Jun Rentschler, Brian Walsh (2018). Building Back Better: Achieving Resilience through Stronger, Faster, and More Inclusive PostDisaster Reconstruction. World Bank, Washington, DC USA. See: WB-BBB [Accessed, 25 December 2020].

69. Christian Bodewig \& Stéphane Hallegatte (2020). Building back better after COVID-19: How social protection can help countries prepare for the impacts of climate change. World Bank Blogs. See: WB-Blogs BBB [Accessed, 26 December 2020]. 